ECONOMICS

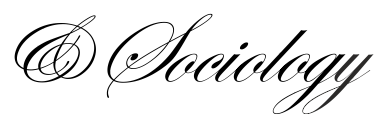

Popoola, O., Alege, P.O., Gershon, O. \& Asaleye, J.A. (2019). Human capital channels and productivity growth: Evidence from Nigeria. Economics and Sociology, 12(4), 59-73. doi:10.14254/2071-789X.2019/12-4/3

\section{HUMAN CAPITAL CHANNELS AND PRODUCTIVITY GROWTH: EVIDENCE FROM NIGERIA}

\author{
Olabisi Popoola, \\ Covenant University, Nigeria \\ Ota, Nigeria \\ popoola.o@lmu.edu.ng \\ Philip Olasupo Alege, \\ Covenant University, Nigeria \\ Ota, Nigeria \\ philip.alege@covenantuniversity.edu.ng \\ Obindah Gershon, \\ Covenant University, Nigeria \\ Ota, Nigeria \\ obindah.gershon@covenantuniversity.edu.ng
}

\author{
Abiola John Asaleye, \\ Landmark University, Nigeria \\ Omu-Aran, Nigeria \\ asaleye.abiola@lmu.edu.ng
}

Received: March, 2019

1st Revision: August, 2019

Accepted: November, 2019

DOI: $10.14254 / 2071-$

789X.2019/12-4/3

JEL Classification: J24, O4, C18

\begin{abstract}
Numerous studies have examined the relationship between human capital and productivity. However, the implications of human capital channels - the 'basic channel' and 'advanced channel' - were discounted from most of the empirical studies in Africa. This study, therefore, uses Vector Error Correction Model to examine the joint short- and long-run causality, as well as long-run behaviour of human capital channels on productivity within the period from 1980 to 2017. Evidence from the joint short- and long-run causality shows that there is no long-run one while joint short-run causality was observed in the basic channel, in the advanced channel there is both joint short- and long-run causality. For the long-run equation, primary school enrollment/secondary school enrollments have insignificant effect on productivity growth while tertiary institution enrollment and government expenditure on education have a positive effect on productivity growth. However, contribution of both effects is less than one per cent, thus showing low responsiveness of the inputs on productivity. The implications from this result are that human capital formation through education and investment in research and development have not promoted productivity in Nigeria. Investment in research and development is imperative to promote productivity and enhance the skills needed to adapt and diffuse new technologies.
\end{abstract}

Keywords: human capital channels, productivity, short-run, long-run, causality

\title{
Introduction
}

Human capital includes acquiring knowledge, ideas, skills and other "invisible" assets of individuals that can be used to create economic value. Investment in human capital is one of the vital factors that promote growth through productivity improvement. Signalling theory also stresses that investment in education is a signal to differentiate the most productive individuals 
during recruitment (Spencer, 1973). In recent times, education has been acknowledged as one of the major channels to increase productivity of human capital (Escosura, \& Roses, 2010; Lee $\&$ Lee, 2016). Consequently, a strand of literature has recognized the importance of human capital for economic productivity (Trostel et al., 2002; Vandenbussche, Aghion \& Meghir, 2006; Li \& Wang, 2016 Dias \& Tebaldi, 2012). At the same time, determining the channels of human capital on growth and development is of main interest to promote sustainability. Another strand of literature shares the view that the presence of human capital does not increase productivity growth in all cases due to external shocks from different production processes and service delivery ( $\mathrm{Li}$, Lai, Wang \& Zhao, 2016). Given this circumstance, it is essential to improve human capacity to adjust to different economic situations. However, an emphasis has been placed on the advanced human capital, the role of which is played by technology and research and development due to their ability to spur innovations, increase aggregate output and reduces marginal costs over time (Romer, 1990; Nelson \& Phelps, 1990). This means that productivity growth can be enhanced if the channels of human capital are improved via development and adoption of new strategies in productive and economic activities.

Likewise, the Sustainable Development Goals (SDGs) 4 stressed the reasons to develop human capital through inclusive and quality education by means of decent work conditions and growth in connection with SDG 8. These goals are particularly relevant for African countries, which have higher percentage of youth population being unemployed (IMF, World Economic Outlook, 2018). Nigeria has abundant human and natural resources but it still faces numerous developmental challenges such as high poverty rate, high unemployment rate and low income per capita (Popoola, Asaleye \& Eluyela, 2018; Asaleye, Olurinola, Oloni \& Ogunjobi, 2017; Asaleye, Popoola, Lawal, Ogundipe \& Ezenwoke, 2018). One of the reasons attributed to low productivity growth, according to some scholars, is low rate of investment in human capital, another reason is the inability to know the right channel of human capital investment to embark on (Li, Lai, Wang \& Zhao, 2016).

Two major channels through which human capital can promote productivity are documented in literature as: the 'basic channel' with the emphasis on human capital to augment production (Lucas, 1998; Li and Wang, 2016; Lerner, 2011; Scott-Clayton, 2013), and secondly, the 'advanced channel' with its emphasis on human capital to increase total factor productivity (Vandenbussche, Aghion \& Meghir, 2006; Tingting \& Wang, 2016; Schultz, 1961; Becker, 1962; Nelson \& Phelps, 1966). Meanwhile, Aghion and Howwi, (1992) posit that human capital affects growth primarily through the advanced channel which was termed the total factor productivity channel. Through this channel, investment in human capital can spur research and development, which, in its turn, will increase the level of technology and innovation. Taking another perspective on the basic channel, human capital can be viewed as a regular production factor, and it is referred to as factor accumulation (Mulligan \& Sala-i-Martin, 1992). Even though theoretical literature has consistently established that human capital has a positive influence on growth, however, the impact through these channels still remains to be understudied. While most of other empirical works on Nigeria did not consider the channels of human capital to promote growth, ignoring these channels in policy discussions related to sustainable growth and development make them less inclusive. The population of Nigeria accounts for about 50 percent of all the West African countries, this is approximately 202 million people with the majority regarded as youth. The country experienced a sharp drop in economic growth in 2015 traceable to oil prices' reduction at international market. Ever since, the growth rate has not increased significantly. In 2018, the growth rate was 1.9 percent and then 2 percent in the first half of 2019. Consequently, the unemployment rate is increasing, in 2018 the unemployment rate was 23 percent while about 20 percent more were underemployed. Scholars have predicted a positive relationship between human capital and overall welfare. Nigeria has recorded improvement in some of socioeconomic factors over the years, however, 
questions have been raised on the role of human capital in promoting growth. For example, the country is ranked 152nd of 157 in the World Bank's 2018 Human Capital Index. Similarly, inequality of income has also been one the macroeconomic problem affecting Nigerian economy. The objective of this study, therefore, is to examine the effect of the two human capital channels on productivity in Nigeria.

The contributions of this current study to existing literature are twofold. Firstly, most of the empirical studies in Africa ignored the 'basic' and the 'advance' channels of human capital on productivity despite the strong theoretical connection established in literature. Also, the study by Li and Wang (2016) investigated these channels using panel data in China but ignored short and long-run impacts. This study uses Vector Error Correction Model (VECM), following Masih and Masih (1996) to investigate the joint short- and long-run causality of human capital channels on productivity. The approach by Pesaran and Shin (1996) was used to examine the long-run behaviour. It is believed that this work will give more insights on investment in human capital with the aim to promote growth within a time dimension for Nigeria and other developing countries with a similar economic structure.

The introductory section here is followed by Section 2, which explores the review of some existing literature related to the study. Then, theoretical framework and model specification are in Section 3. Presentation of results is in Section 4, while Section 5 provides conclusions and recommendations

\section{Literature review}

Theoretically, there is no consensus of the implications of human capital through different channels on production. One strand of economic literature believes that human capital affects productivity merely through the input factor used in production activity referred to as basic channel of human capital (Lucas, Mankiw, Romer \& Weil, 1992; Molligan, Sala-i-Martin, 1992; Lerner, 2011; Scott-Clayton, 2013). According to this view, human capital input augments the production activity without increasing the total factor productivity, that is, the accumulation of human capital increases productivity through the input factor only. The second strand of literature shared the perspective that human capital is essential to increase total factor production, this channel is termed the advanced channel of human capital (Vandenbussche, Aghion \& Meghir, 2006; Romer, 1990; Aghion \& Howitt, 1992; Nelson \& Phelps, 1990; Schultz, 1961; Becker, 1962; Nelson \& Phelps, 1966).The advanced channel includes investment in research and development and the enhancement of skills to adapt and diffuse new technologies. While another strand of literature documented that no significant connection between human capital channels and productivity due to many factors, such as the effect of external shocks from different production processes and service delivery (Li, Lai, Wang \& Zhao, 2016). Li and Wang (2016) pointed out that understanding the connection between human capital and productivity does not only depend on other factor inputs but on the differences among the level of human capital in each given countries. Consequently, Dias and Tebaldi (2012) shared the view that investment in human capital through the advanced channel and improved institution will not only promote growth but also will increase overall welfare by promoting equality in the distribution of income and change the historical development path. More so, Becker (1964) showed that there is a positive relationship between educational outcomes and economic outcomes.

Empirically, several studies have been undertaken to analyze the impact of human capital on growth, however, most of these studies did not emphasise on the channels of human to promote growth. Although, it was documented that various metrics of human capital affect the economy differently; few among others include the studies by Su and Liu (2016) that investigated the impact of foreign direct investment (FDI) and human capital on economic 
growth in Chinese cities using panel data. Also, Teixera and Queiros (2016) investigated the relationship between economic growth, human capital and structural change using a dynamic panel data estimation model. In a similar study, Onkelinx, Manolova, Edelman (2016) carried out a study on the nexus among investments and employee human capital, productivity, and SME internationalization in Belgium using ordinary least square regression and generalized two-stage least squares regressions. Benos and Karagiannis (2016) studied the effect of education quality and spillovers on human capital and productivity in Greece. Benos and Karagiannis (2016) documented a strong negative impact of primary education and a positive effect of secondary and tertiary education on labour productivity. Consequently, Chang, Wang, and Lui (2016) examined knowledge spillovers, human capital and productivity in Taiwan using ordinary least squares estimation method. It was discovered that human capital spillovers are not only present but with more influence under technology intensities. While Ogundari and Awokuse (2018) examined the contribution of human capital to economic growth in SubSaharan Africa, using a system generalized method of moments. The scholars show that human capital has positive effects on economic growth. Although, the study by Liu and Wang (2016) investigated channels of human capital on growth in China using GMM. However, the study by the scholars did not consider the time perspective effects.

Most of the empirical literature in relation to human capital and macroeconomic performance is filled with mixed result. This also reverberated in the study by Dutta and Sobel (2017). This reason may be that most of these empirical studies are carried out using crosscountry analysis, most especially in Africa (Gyimah-Brempony \& Wilson, 2004, GyimahBrempony, Paddison \& Mitiku, 2006; Gleww, Maiga \& Zheng, 2014; Ogundari \& Awukuse, 2018). The cross-country analysis may help to understand the impact but may not give insight to the growth process (Fashina, Asaleye, Ogunjobi \& Lawal, 2017; Asaleye, Lawal, Popoola; Alege \& Oyetade, 2019). Although, the theoretical literature has unanimously established that human capital significantly has a positive impact on growth, however, the impact through the channels remains undecided (Lucas, Mankiw, Romer \& Weil, 1992; Molligan, Sala-i-Martin, 1992; Vandenbussche, Aghion \& Meghir, 2006). Several scholars have examined the implications of human capital in business cycle. Few among others include the study by Perli and Sakellaris (1998) that worked on human capital formation and business cycle persistence. In addition, Kim and Lee (2007) examined the nexus among on-the-job human capital accumulation and skill acquired in real business cycle. Kim and Lee (2007) emphasised that the opportunity cost of time invested in acquiring human capital moves pro cyclically, hence, onthe-job time invested in acquired human capital is 'counter cyclical'. In a similar work, Alessandrini, Kosempel and Stengos (2015) that investigated the relationship between hours worked volatility and human capital investment in business cycle settings. The scholars concluded that individuals invest more in human capital during economic downturns. While most of the other empirical works in Nigeria did not consider the channels of human capital on growth (Ogunleye et al, 2017; Eigbiremolen \& Anaduaka, 2014; Adelakun, 2011). As such, this study fills the gap in the literature by examining both the short and long-run effects of human capital channels on productivity in Nigeria.

\section{Methodological approach}

\subsection{Theoretical Framework}

This study adapted the model by Li and Wang (2016) using the Solow growth model. It is an improvement version of the original growth model, which did not include human capital. Mankiw, Romer, and Weil (1992) developed the augmented Solow model in order to justify 
the necessity for the inclusion of human capital in the growth model. This is because of the nonhomogeneity of labour in the process of production either across different nations or within a nation due to their different level of skills and educational attainment. The theory is very sustainable and adaptable in a country like Nigeria because the theory assumes that an increase in the quality of workers via educational improvement will lead to improvement in output. In other words, the model acknowledges the importance of human capital than only physical labour and capital. The production function is specified as:

$$
P R O G_{t}=A_{t} C A P_{t} H C_{t} L A B_{t}
$$

The standard growth model indicates that capital and labour inputs are necessary to increase the level of outputs. Consquenctly, studies have stressed that human capital input should be considered to increase the level of aggregate output (Gyimah-Brempony, Paddison \& Mitiku, 2006). In equation $1, P R O G$ is output level; $C A P$ is stock of physical capital; $H C$ is level of human capital; $L A B$ is labour, A is level of total factor productivity. Likewise, $L A B$ and $A$ are assumed to grow exogenously at rate $\mathrm{m}$ and $\mathrm{q}$ at the time ( $\mathrm{t}$ ) respectively:

$$
\begin{aligned}
& L A B_{t}=L A B_{0} e^{m t} \\
& A_{t}=A_{0} e^{q t}
\end{aligned}
$$

Equation 1 can be expressed in the per-capital form as follows:

$$
P R O G_{t}=A_{t} C A P_{t}^{\beta_{1}} H C_{t}^{\beta_{2}} L A B_{t}^{\beta_{3}}
$$

In equation $4, P R O G_{t}=\frac{P R O G_{t}}{L A B_{t}}$ is per capita real output, $C A P_{t}=\frac{C A P_{t}}{L A B_{t}}$ is the capitallabour ratio, and $H C_{t}=\frac{H C_{t}}{L A B_{t}}$ is the average human capital.

Putting equation 4 in a $\log$ form, then the equation is expressed as:

$$
\operatorname{In} \mathrm{P} R O G_{t}=\operatorname{In} A_{t}+\beta_{1} \operatorname{InCAP} P_{t}+\beta_{2} \operatorname{In} H C_{t}+\beta_{3} \operatorname{InLAB} B_{t}+\varepsilon_{t}
$$

Substituting both equations 2 and 3 into 5 yields the growth accounting regression (GAR) for the basic channel:

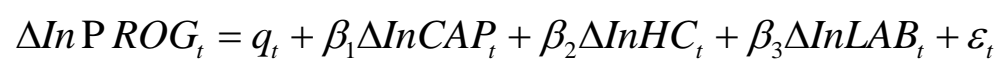

In equation $6, q_{t}=\operatorname{In} A_{t}$ and it is exogenously determined representing the constant rate of technological progress. This equation 6 represents the basic human capital or accumulation channel. To establish the equation for the advanced channel, expressing the total factor productivity in relation to average human capital $H C_{t}$ with the consideration between the level of innovation theoretically and the actual level gives:

$$
\frac{A_{t}}{A_{t}}=\lambda H C_{t}\left[\frac{T C E_{t}-A_{t}}{A_{t}}\right] \lambda_{0}=\lambda_{H C}^{t}>0
$$

The growth rate of the level of technology given by $A_{t}$ is an increasing function of human capital $H C_{t}$ and proportion of the gap measured by: $\left[\frac{T C E_{t}-A_{t}}{A_{t}}\right]$ Also, $q_{t}$ is an extensive independent, however, dependent on the level of human capital which also depend on the process of $H C_{t}$. Hence, the output function with respect to the human capital channel can be expressed as:

$$
P R O G_{t}=A\left(H C_{t}\right) C A P_{t}^{\alpha_{1}} L A B_{t}^{\alpha_{2}}
$$

Putting equation 8 in $\log$ form gives

$$
\operatorname{InPROG}_{t}=\operatorname{InA}\left(H C_{t}\right)+\alpha_{1} \operatorname{InCAP} P_{t}+\alpha_{2} \operatorname{In} L A B_{t}+v_{t}
$$


Equation 9 is modified like equation 6 used to derive the advanced channel and the GAR, given that:

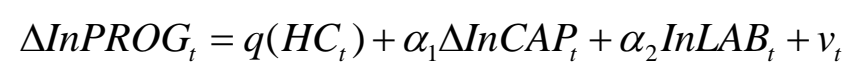

Since the total factor productivity (TFP) growth rate $q\left(H C_{t}\right)$ is increasing in $H C_{t}$, the above equation can be simplified to get the regression model for the productivity channel.

$$
\triangle I n P R O G_{t}=c_{t}+\alpha_{1} \Delta \operatorname{InCAP} P_{t}+\alpha_{2} \operatorname{In} L A B_{t}+\alpha_{3} M_{t}+v_{t}
$$

Similarly, in equation 11 an increase in the level of human capital will propel effectively and sustain effect on productivity channel rather than just an increase in output as stressed in the basic channel. The variable ' $M$ ' represents the advanced channel indicator. In this study, the basic channel indicators are primary and secondary school enrolment while the advanced channel indicators are tertiary enrollment and government expenditure in higher institutions ${ }^{1}$.

The joint effects of both channels are also investigated, to achieve this, the basic human capital will be denoted by $g H C_{t}$ and advance human capital will be denoted by $j H C_{t}$. The production function is given as:

$$
P R O G_{t}=A(g H C) C A P_{t}^{\lambda_{1}}\left(j H C_{t}\right)^{\lambda_{2}} L A B_{t}^{\lambda_{3}}
$$

So, the regression model becomes:

$$
\Delta \operatorname{In}\left(P R O G_{t}\right)=\operatorname{In} A(g H C)+\lambda_{1} \Delta C A P_{t}+\lambda_{2} \operatorname{In}\left(j H C_{t}\right)+\lambda_{3} \operatorname{In} L A B_{t}+\mu_{t}
$$

Like equation 9 , for productivity channel, the level of independent technological growth rate $A(g H C)$ is also an increasing function of $g H C$. Then, equation 13 implies that growth is influenced by the stage of advanced human capital via $A(g H C)$ and the rate of accumulation of the basic human capital $j H C$. The variant of the GAR for the combined channels is given as:

$$
\Delta \operatorname{In}\left(P R O G_{t}\right)=c_{t}++\lambda_{1} \operatorname{In}\left(j H C_{t}\right)+\lambda_{2} \ln \left(g H C_{t}\right)+\lambda_{3} \ln \left(L A B_{t}\right)+\lambda_{4} \Delta \ln \left(C A P_{t}\right)+\mu_{t}
$$

Equation 14 shows the joint effect of both the basic and the advanced channel of human capital on productivity.

\subsection{Model Specification and Technique of Estimations}

Following the theoretical framework, the models for the basic channel, advanced channel and the aggregate channel which comprises of both basic channel and advanced channel using equations (6), (11) and (14) respectively are stated as follows;

\section{Basic Channel}

To measure the basic human capital effect on growth, the model from equation 6 is modified and expressed in equation 15. In this equation, the primary school and secondary school enrollments were used as proxies for the basic channel indicators.

$\Delta \ln \left(P R O G_{t}\right)=\beta_{0}+\beta_{1} \Delta \ln \left(P S E R_{t}\right)+\beta_{2} \Delta \operatorname{In}\left(S S E R_{t}\right)+\beta_{3} \Delta \ln \left(L A B_{t}\right)+\beta_{4} \Delta \ln \left(C A P_{t}\right)+\varepsilon_{t}$

$P S E R$ represents the primary school enrolment and SSER represent the secondary school enrolments, the variables $L A B$ and $C A P$ are labour and capital respectively. The model is given in ECM form as:

$$
\Delta I n\left(P_{R O G}\right)=\beta_{0}+\beta_{1} \Delta \operatorname{In}\left(\operatorname{PSER}_{t-1}\right)+\beta_{2} \Delta \operatorname{In}\left(\operatorname{SSER}_{t-1}\right)+\beta_{3} \Delta \operatorname{In}\left(L A B_{t-1}\right)+\beta_{4} \Delta \operatorname{In}\left(C A P_{t-1}\right)+\beta_{5} E C T_{t-1}+\varepsilon_{t} 16
$$

\footnotetext{
${ }^{1}$ The indicators are limited due to scanty of data on human capital.
} 


\section{Advanced Channel}

To measure the effectiveness of the advance channel of human capital on productivity, the model from equation 11 is adjusted and becomes:

$$
\Delta \ln \left(P R O G_{t}\right)=\alpha_{0}+\alpha_{1} \Delta \ln \left(G E E_{t}\right)+\alpha_{2} \Delta \ln \left(T I E R_{t}\right)+\alpha_{3} \Delta \operatorname{In}\left(L A B_{t}\right)+\alpha_{4} \Delta \operatorname{In}\left(C A P_{t}\right)+v_{t}
$$

In equation $17, G E E$ represent government expenditure on education which comprises of current and capital expenditure in higher institutions and expenditure on research and development. TIER is the tertiary enrolment, the variables $L A B$ and $C A P$ are labour and capital respectively ${ }^{2}$. The ECM form is given as:

$$
\Delta \operatorname{In}\left(\text { PROG }_{t}\right)=\alpha_{0}+\alpha_{1} \Delta \operatorname{In}\left(G E E_{t-1}\right)+\alpha_{2} \Delta \operatorname{In}\left(\operatorname{TIER}_{t-1}\right)+\alpha_{3} \Delta \operatorname{In}\left(L A B_{t-1}\right)+\alpha_{4} \Delta \operatorname{In}\left(C A P_{t-1}\right)+\alpha_{5} E C T_{t-1}+v_{t}
$$

\section{Aggregate Channel}

The aggregate channel is the extensive form of the models; it comprises the basic and advanced channels implication on productivity. From equation 14, the extensive effect is expressed as follows:

$$
\Delta \operatorname{In}\left(P R O G_{t}\right)=c_{t}++\lambda_{1} \operatorname{In}\left(j H C_{t}\right)+\lambda_{2} \ln \left(g H C_{t}\right)+\lambda_{3} \ln \left(L A B_{t}\right)+\lambda_{4} \Delta \ln (C A P)_{t}+\mu_{t}
$$

Where $P R O G=$ Productivity Growth; PSER $=$ Primary School Enrolment, SSER $=$ Secondary School Enrolment; TIER = Tertiary Education Enrolment; and GEE= Government Expenditure on Education. $g H C_{t}$ represents the basic channel indicators which combined of $P S E R_{t}$ and $S S E R_{t}$ while $j H C_{t}$ represents the advanced channel indicators which combined of $G E E_{t}$ and $T I E R_{t}$. Stated in ECM form as;

$$
\Delta \operatorname{In}\left(P_{R O G}\right)=\lambda_{0}+\lambda_{1} \Delta \operatorname{In}\left(j H C_{t-1}\right)+\lambda_{2} \Delta \operatorname{IIn}\left(g H C_{t-1}\right)+\lambda_{3} \Delta \operatorname{In}\left(L A B_{t-1}\right)+\lambda_{4} \Delta \operatorname{In}\left(C A P_{t-1}\right)+\lambda_{5} E C T_{t-1}+\mu_{t}
$$

This study carried out the unit root test on the series using Augmented Dickey-Fuller approach and the number of the cointegrating vectors (s) was determined using the Johansen approach ${ }^{3}$. Afterwards, the joint short and long-run were examined following Masih and Masih (1996) approach. This was done by imposing restrictions on the system of equations from the Vector Error Correction Model (VECM). The idea is to determine if the variables jointly explained the productivity with respect to period perspective, short and long-run. The VECM equation is given as follows;

$$
\Delta y_{t}=\delta_{o}+\delta_{1 x} K-\prod_{x} R_{t-1}+\sum_{i=1}^{\rho-1} \Gamma_{1 x} \Delta R_{t-1}+N_{x} Z_{t}+\gamma E_{t}+\mu_{t}
$$

In equation $21, \Gamma_{1 x}$ is the short-run matrix of the parameters, $\Pi_{x}$ is the long-run multiplier matrix, $Z_{t}$ is the vector of exogenous variables in order $1, E_{t}$ is the vector of jointly determined endogenous non-stationary variables. This study follows Pesaran and Shin (1996) to establish the long-run relationship in basic, advanced and aggregate channels. The effects of employment and capital were isolated in the long-run behaviour. This was done to be able to understand how these channels affect productivity in Nigeria. The Wald test statistics were used to investigate the short-run causality. The null hypothesis involves testing if the independent variables and the lags are statistically different from zero. Likewise, the joint long-run causality was established from the residual. The negative sign, less than one coefficient and significance of the residuals shows that the independent variables and the lags jointly explained the dependent variable in the long-run

\footnotetext{
${ }^{2}$ To capture the long run effect of human on productivity, the labour and capital inputs are excluded in the analysis in section 4

${ }^{3}$ The result of Johansen is used to determine the number of cointegrating vectors and is available with authors, can be provided upon request.
} 


\section{Source of Data}

This study employs time series secondary data collected on the variables specified in the model from the period 1980 to 2017.

\begin{tabular}{|c|c|c|c|}
\hline Series & Measurement & Apriori & Sources of Data \\
\hline $\begin{array}{l}\text { Secondary School } \\
\text { Enrollment (SSER)/ } \\
\text { Primary School } \\
\text { Enrolment (PSER) } \\
\end{array}$ & $\begin{array}{l}\text { A measure for basic human } \\
\text { capital; secondary and primary } \\
\text { school education }\end{array}$ & $\begin{array}{l}\text { Positive or } \\
\text { Negative }\end{array}$ & $\begin{array}{l}\text { World Development } \\
\text { Indicator (WDI) } 2017\end{array}$ \\
\hline $\begin{array}{l}\text { Tertiary Institution } \\
\text { Enrollment (TIER) }\end{array}$ & $\begin{array}{l}\text { A measure for advance human } \\
\text { capital: University } \\
\text { education/Post Graduate study }\end{array}$ & Positive & $\begin{array}{l}\text { Federal Ministry of } \\
\text { Education, Lagos }\end{array}$ \\
\hline $\begin{array}{l}\text { Government } \\
\text { Expenditure on } \\
\text { Education (GEE) }\end{array}$ & $\begin{array}{l}\text { This is the total expenditure the } \\
\text { government spending on higher } \\
\text { education in Nigeria, including } \\
\text { expenditure on research and } \\
\text { development. }\end{array}$ & Positive & CBN \\
\hline Productivity Growth & $\begin{array}{l}\text { Productivity growth is measured } \\
\text { by dividing RGDP with Working } \\
\text { Population }\end{array}$ & $\begin{array}{l}\text { Dependent } \\
\text { Variable }\end{array}$ & $\mathrm{CBN}$ and WDI \\
\hline $\begin{array}{l}\text { Employment } \\
\text { Growth Rate }\end{array}$ & Total employment in Nigeria & Positive & $\begin{array}{l}\text { Nigerian Bureau of } \\
\text { Statistics (NBS) }\end{array}$ \\
\hline Capital Growth Rate & Gross Fixed Capital Formation & Positive & $\mathrm{CBN}$ \\
\hline
\end{tabular}

\section{Conducting research and results}

\subsection{Presentation of Result}

Table 1. Summary of ADF Unit Root Test Results

\begin{tabular}{|c|c|c|c|c|c|c|}
\hline \multirow[t]{3}{*}{ Series } & \multicolumn{2}{|c|}{ ADF Result } & \multicolumn{3}{|c|}{ Mackinnon Critical Value } & \multirow{3}{*}{$\begin{array}{c}\text { Order of } \\
\text { Integration }\end{array}$} \\
\hline & \multirow[t]{2}{*}{ Level } & \multirow[t]{2}{*}{ First Diff } & & & & \\
\hline & & & 1 per cent & 5 per cent & 10 per cent & \\
\hline $\ln P R D G$ & 0.28828 & -7.50693 & -3.62678 & -2.94584 & -2.61153 & $\mathrm{I}(1)$ \\
\hline $\ln G E E$ & -1.64249 & -5.077317 & -3.62678 & -2.94584 & -2.61153 & $\mathrm{I}(1)$ \\
\hline InPSER & -1.57791 & -5.764657 & -3.62678 & -2.94584 & -2.61153 & $\mathrm{I}(1)$ \\
\hline $\ln S S E R$ & -1.48373 & -5.913114 & -3.62678 & -2.94584 & -2.61153 & $\mathrm{I}(1)$ \\
\hline $\operatorname{lnTIER}$ & -2.41286 & -5.652761 & -3.62678 & -2.94584 & -2.61153 & $\mathrm{I}(1)$ \\
\hline $\operatorname{In} L A B$ & -1.45024 & -3.712390 & -3.62678 & -2.94584 & -2.61153 & $\mathrm{I}(1)$ \\
\hline InCAP & -0.67568 & -3.650458 & -3.62678 & -2.94584 & -2.61153 & $\mathrm{I}(1)$ \\
\hline
\end{tabular}

Source: Authors' Computation using Eviews 10

Table1 presents the summary of the unit root test results for the series in level and in first difference forms. The result of the ADF shows that all the variables are stationary at first differencing since the absolute value of ADF statistics exceeded the critical value at the level of 5 per cent significance level. This shows that all series are integrated of the same order. Based on the outcome, the study estimated the Vector Error Correction Model (VECM), from the VECM, the joint short and long-run causality was established. 
Table 2. Basic Channel: Joint Short and Long-run Causality

\begin{tabular}{|c|c|c|c|c|}
\hline \multicolumn{5}{|c|}{ Joint Long-run Causality } \\
\hline Coefficient & Std. Error & t-statistics & Prob. & Hypothesis Testing \\
\hline 0.020373 & 0.050532 & 0.403176 & 0.6900 & Accepted \\
\hline \multicolumn{5}{|c|}{ Joint Short-run Causality } \\
\hline \multicolumn{2}{|c|}{ Null Hypothesis } & Chi-square & Prob. & Hypothesis Testing \\
\hline \multicolumn{2}{|c|}{$C(1): C(7)=0$} & 25.64931 & 0.0006 & Rejected \\
\hline \multicolumn{5}{|c|}{ Diagnostic Check } \\
\hline \multicolumn{5}{|c|}{ Histogram Normality Test } \\
\hline \multicolumn{3}{|c|}{ Jarque-Bera Value: $\mathbf{1 . 9 7 1 0 2 9}$} & \multicolumn{2}{|c|}{ Prob.: 0.373247} \\
\hline \multicolumn{5}{|c|}{ Serial Correlation LM Test } \\
\hline \multicolumn{3}{|c|}{ Obs.* R-squared: $\mathbf{2 . 1 2 7 8 6 3}$} & \multicolumn{2}{|c|}{ Prob.: 0.3451} \\
\hline \multicolumn{5}{|c|}{ Heteroskedasticity Test } \\
\hline \multicolumn{3}{|c|}{ Obs.* R-squared: 0.679098} & Prob.: & \\
\hline
\end{tabular}

Source: Authors Computation using Eviews 10

From table 2, the null hypothesis that there is no joint-run causality is accepted. The coefficient of cointegrating equation, that is the long-run causality shows that there is no joint causality between productivity growth (PRDG) and the basic channels of human capital (PSER/SSER) in the long-run, since the probability value is greater than 0.05 , this implies that the variable is insignificant at 5 per cent level. From the same table we have the result of the joint short-run causality between the variables; the coefficients of the cointegrating equation are $\mathrm{C}(1)$ to $\mathrm{C}(7)$, and the result revealed that there is a short-run causality between productivity growth and the basic human capital, this is because the probability of the Chi-square is less than 0.05. Therefore, the null hypothesis that there is no short-run causality is rejected.

The diagnostic checks were used to access whether the model is correctly specified; the Jarque-Bera value was used for the normality test, it shows that the residual is normally distributed; since the Jarque-Bera Statistics is greater than 5 per cent. Therefore, the null hypothesis that residuals are not normally distributed is rejected.The serial correlation test shows that there is no serial correlation in the model; this is because the probability value is higher than 5 per cent. The Chi-square probability value for heteroskedasticity test shows that there is no ARCH effect; this is because the probability value is greater than 5 per cent.

Table 3. Advanced Channel: Joint Short and Long-run Causality

\begin{tabular}{|c|c|c|c|c|}
\hline \multicolumn{5}{|c|}{ Joint Long-run Causality } \\
\hline Coefficient & Std. Error & t-statistics & Prob. & Hypothesis Testing \\
\hline-0.178488 & 0.054644 & -3.266378 & 0.0030 & Rejected \\
\hline \multicolumn{5}{|c|}{ Joint Short-run Causality } \\
\hline \multicolumn{2}{|c|}{ Null Hypothesis } & Chi-square & Prob. & Hypothesis Testing \\
\hline \multicolumn{2}{|c|}{$C(1): C(7)=0$} & 45.88748 & 0.0000 & Rejected \\
\hline \multicolumn{5}{|c|}{ Diagnostic Check } \\
\hline \multicolumn{5}{|c|}{ Histogram Normality Test } \\
\hline \multicolumn{3}{|c|}{ Jarque-Bera Value: $\mathbf{0 . 2 7 2 9 7 9}$} & \multicolumn{2}{|c|}{ Prob.: 0.872415} \\
\hline \multicolumn{5}{|c|}{ Serial Correlation LM Test } \\
\hline \multicolumn{3}{|c|}{ Obs.* R-squared: $\mathbf{0 . 6 0 1 8 6 1}$} & \multicolumn{2}{|c|}{ Prob.: 0.7401} \\
\hline \multicolumn{5}{|c|}{ Heteroskedasticity Test } \\
\hline \multicolumn{3}{|c|}{ Obs.* R-squared: 4.113727} & Prob.: ( & \\
\hline
\end{tabular}

Source: Authors Computation using Eviews 10 
Table 3 shows the long-run and short-run causality between productivity growth and the advanced channel of human capital; the coefficient of cointegrating equation for the long-run causality shows that there is joint causality between productivity growth (PRDG) and advance channels of human capital (GEE and TIER) in the long-run at 5 per cent level of significance. $\mathrm{C}(1)$ to $\mathrm{C}(7)$ are the coefficients of the cointegrating equation and the result of the joint shortrun causality shows that the probability of the Chi-square is less than 0.05 implying that there is joint short-run causality between productivity growth and the advance human capital. The Jarque-Bera value shows that the residual is normally distributed; this is because the JarqueBera Statistics is greater than 5 per cent. There is an absence of serial correlation because the probability value is higher than 5 per cent. Likewise, in the heteroskedasticity test, the Chisquare probability value greater than 5 per cent implies that there is no $\mathrm{ARCH}$ effect.

Table 4. Aggregate Channel: Joint Short and Long-run Causality

\begin{tabular}{llll}
\hline Joint Long-run Causality & & & \\
\hline Coefficient $\quad$ Std. Error & t-statistics & Prob. & Hypothesis Testing \\
\hline $\mathbf{- 0 . 2 9 0 6 8 3} \quad 0.070058$ & -4.149159 & 0.0004 & Rejected \\
\hline Joint Short-run Causality & & & \\
\hline Null Hypothesis & Chi-square & Prob. & Hypothesis Testing \\
\hline C(1) $\mathbf{~ C ( 1 1 ) ~} \mathbf{0}$ & 56.75472 & 0.000 & Rejected \\
\hline Diagnostic Check & & & \\
\hline Histogram Normality Test & & \\
\hline Jarque-Bera Value: $\mathbf{0 . 0 3 4 0 0 8}$ & Prob.: 0.983140 \\
\hline Serial Correlation LM Test & & \\
\hline Obs.* R-squared: $\mathbf{1 . 2 3 8 5 8 5}$ & Prob.: 0.5383 \\
\hline Heteroskedasticity Test & \\
\hline Obs.* R-squared: $\mathbf{0 . 0 7 3 2 5 2}$ & Prob.: 0.9640 \\
\hline
\end{tabular}

Source: Authors Computation using Eviews 10

Table 4 explains the effect of the aggregate channel of human capital (basic and advance channel) on productivity growth; the result of the coefficient of the cointegrating equation for the long-run causality revealed that there is joint long-run causality between productivity growth and the aggregate channel (basic and advance channel ) of human capital. The probability value is lesser than 5 per cent. The $C$ (1) to $C$ (11) are the coefficients of the cointegrating equation (joint short-run causality). The probability of Chi-square is less than 0.05 implying that there is joint short-run causality between productivity growth and the aggregate channels (basic and advance channels) of human capital. Therefore, the null hypothesis that there is no long-run causality and the short-run causality is rejected for the aggregate channels. The result of the normality test shows that the residual is normally distributed; this is because the Jarque-Bera Statistics is greater than 0.05. For the serial correlation, the probability value is higher than 0.05 , this means there is no serial correlation, hence the null hypothesis is accepted. The Chi-square probability value for heteroskedasticity test shows that there is no $\mathrm{ARCH}$ effect, this is because the probability value is greater than 0.05 .

Table 5 presents the result of the long-run cointegrating vectors of productivity growth and the various human capital channels; due to the normalized process, the signs are revert in the interpretations. The result of the basic channel shows that the coefficient of primary school enrollment has a negative relationship with productivity while secondary school enrollment is not statistically significant at the level of 5 per cent. On the advance channel,government expenditure on tertiary education has a positive and significant effect on productivity growth while territory has a negative implication. For the aggregate channels, primary school 
enrollment/secondary school enrollments have an insignificant effect on productivity growth while tertiary institution enrollment and government expenditure on education has a positive effect on productivity growth.

Table 5. Long-run Equation

\begin{tabular}{lllllrr}
\hline \multicolumn{2}{l}{ Basic Channel } \\
\hline PRGD & PSER & SSER & TIER & GEE & LAB & CAP \\
\hline $\mathbf{1}$ & $0.000164^{*}$ & -0.000148 & 0 & 0 & 0 & 0 \\
& $(0.000039)$ & $(0.00084)$ & & & & \\
\hline \multicolumn{2}{l}{ Advanced Channel } & & & & & \\
\hline PRDG & PSER & SSER & TIER & GEE & LAB & CAP \\
\hline $\mathbf{1}$ & 0 & 0 & $0.000114^{*}$ & $-0.0000944^{*}$ & 0 & 0 \\
& & $(0.00082)$ & $(0.00018)$ & & \\
\hline \multicolumn{2}{l}{ Aggregate Channel } & & & & & CAB \\
\hline PRDG & PSER & SSER & TIER & GEE & 0 \\
\hline $\mathbf{1}$ & 0.000217 & 0.000417 & $-0.00413^{*}$ & $-0.00526^{*}$ & 0 & 0 \\
& $(0.006201)$ & $(0.001800)$ & $(0.000044)$ & $(0.00023)$ & & \\
\hline
\end{tabular}

*shows significance at the level of 5 per cent

The standard error in parentheses

Source: Authors Computation using Eviews 10

\subsection{Discussion of Findings}

This study carried out unit root and cointegration tests to determine the properties of the time series. The unit root test using Augmented Dickey-Fuller test revealed that all series are not stationary at the level form. However, all the series are stationary at first difference form. The cointegration result showed that there is one cointegration vector in all the models. Based on the outcome of the unit root test and cointegration test, the study proceeds to estimate the Vector Error Correction Model (VECM), from this system of equations, the joint short and long run was estimated following Masih and Masih (1996) approach. Three channels of human capital, namely; basic, advanced and aggregate were investigated on productivity in Nigeria. Evidence from the joint short and long-run causality on productivity in Nigeria shows that there is no long-run while joint short-run causality was observed, in the advanced and aggregated channels, there is both joint short and long-run causality. These findings contradict the studies by Lucas, Mankiw, Romer \& Weil (1992); Molligan Sala-i-Maetin (1992); Onkelinx, Manolova \& Edelman (2016) that emphasize the influence of human capital on productivity and development through the basic channel. However, the findings are in line with the studies of Vandenbussche, Aghion and Meghir (2006); Romer (1990); Aghion and Howitt (1992); Nelson and Phelps (1990); Su and Liu (2016); Ogundari and Awokuse (2018) that stressed the impact of human capital on growth and development through the advanced channel. The implication of the result is that Nigeria can promote long-run productivity through joint investment in education in higher institution and improvements in enrollment while joint improvement in enrollment in secondary and primary can be focused more to improve shortrun productivity.

The long-run equation for the basic channel shows that the coefficient of primary school enrollment has a negative relationship with productivity while secondary school enrollment is not statistically significant at the level of 5 per cent. On the advance channel, tertiary enrollment has a negative significant impact on productivity growth while government expenditure on tertiary education has a positive and significant effect on productivity growth. For the aggregate 
channels, primary school enrollment/secondary school enrollments have an insignificant effect on productivity growth while tertiary institution enrollment and government expenditure on education has a positive effect on productivity growth. Although, in the advanced channel longrun equation, the tertiary enrollment has a negative effect on productivity the combined effect with others factors resulted to positive effects has shown in the 'aggregate equation' in table 5. This might due to the complementary nature of the inputs factors. However, the contribution of both effect is less than one per cent showing low responsiveness of the inputs on productivity. These findings are in line with the work of Li and Wang (2016). Similarly, the findings are in line with the study of Karagiannis (2016) who documented a negative relationship between primary school enrolment on output and a positive impact of tertiary enrolment on output. The result is also similar to the aggregate channel, where the indicators for the advanced channel are economically and statistically significant. The implications of this result show human capital formation through education and investment in research and development have not promoted productivity in Nigeria. Although, there is a tendency to maximize the long-run benefit of the advanced channel indicators on productivity if necessary strategies are mapped out to achieve this purpose.

\section{Conclusion}

Nigeria has abundant human and natural resources but faces numerous developmental challenges such as high poverty rate, high employment rate and low income per capita. One of the reasons attributed to low productivity growth according to some scholars is because of low investment rate in human capital and the inability to know the right channel of human capital to invest per time. Although, several studies have been carried out on the implications of human capital on economic growth and development in developing economies. However, empirical analysis of the human channels on growth and development is of foremost importance. Likewise, ignoring these channels make policy discussion for sustainable growth and development less comprehensive. Two major channels in which human capital can promote productivity are documented in the literature namely; the 'basic channel' with emphasis on human capital to augment production Secondly, the 'advanced channel' with emphasis on human capital to increase total factor productivity via technology and innovation. This study, therefore, examines the implications of the two human capital channels on productivity in Nigeria.

As such, this study fills the gap in the literature by examining both the joint short and long-run impacts of human capital on productivity following the approach outlined by Masih and Masih (1996) while Pesaran and Shin (1996) approach were followed to establish the longrun relationship. Evidence from the joint short and long-run causality shows that there is no long-run while joint short-run causality was observed in the basic channel, in the advanced and aggregated channels, there is both joint short and long-run causality. The implication of the result is that Nigeria can promote long-run productivity through joint investment in education in higher institution and improvements in enrollment while joint improvement in enrollment in secondary and primary can be more focused on to improve short-run productivity. The longrun equation for the basic channel shows that the coefficient of primary school enrollment has a negative relationship with productivity, while secondary school enrollment is not statistically significant. On the advance channel, tertiary enrollment has a negative significant impact on productivity growth while government expenditure on tertiary education has a positive effect on productivity growth. For the aggregate channels, primary school enrollment/secondary school enrollments have an insignificant effect on productivity growth while tertiary institution enrollment and government expenditure on education has a positive effect on productivity growth. Nevertheless, the coefficients of the advanced channel are quite low. The implications 
of this result show human capital formation through education and investment in research and development have not promoted productivity in Nigeria. So need to increase investment in research and development is imperative to promote productivity and enhance skills needed to adapt and diffuse new technologies. Also, there is a need for resource reallocation and ensure an effective connection between productivity and human capital both in the short and long-run. This can be achieved by adopting methods of systematic approaches in higher institutions, research and development centres that aim to resolve real-world problems situations critically.

This study is limited due to unavailability of disaggregated data on employment in the primary, secondary and tertiary schools, data on government expenditure in primary and secondary schools, data on employee and their qualifications in Nigerian schools. However, this study uses the available data to investigate the effect of human capital channels on productivity and it is believed that it will help to maximise the benefit of education on productivity in Nigeria. The focus of this study is on the basic and advanced channels of human capital and its connection with productivity, other factors such as emotional and social that affect productivity are not considered. Therefore, it is suggested that future study can incorporate these factors in the human capital channels.

\section{References}

Adelakun, O.J. (2011). Human capital development and economic growth in Nigeria. European Journal of Business and Management, 3(9), 29-38.

Aghion, P., \& Howitt, P. (1992). A model of growth through creative destruction. Econometrica, 60(2), 323-351.

Alessandrini, D., Kosempel, S., \& Stengos, T. (2015). The Business Cycle Human Capital Accumulation Nexus and its Effect on Hours Worked Volatility. Journal of Economic Dynamics and Control, 51, 356 - 377. http://dx.doi.org/10.1016/j.jedc.2014.11.004

Asaleye, A.J, Lawal, A.I, Popoola, O., Alege, O.P., \& Oyetade, O. (2019). Financial integration and employment nexus; evidence from Nigeria. Montenegrin Journal of Economics, (15)1, 141-154. https://doi.org/10.14254/1800-5845/2019.15-1.11

Asaleye, A.J, Popoola, O., Lawal, A.I, Ogundipe, A., \& Ezenwoke, O. (2018). The credit channels of monetary policy transmission: implications on output and employment in Nigeria. Banks and Bank Systems, 13(4), 103-118. https://doi.org/10.21511/bbs.13(4).2018.10

Asaleye, A. J., Olurinola, I., Oloni, E. F., \& Ogunjobi, O. (2017). Productivity growth, wages and employment nexus: Evidence from Nigeria. Journal of Applied Economic Sciences, XII, 5(51), 1362-1376.

Becker, G. (1964). Human capital. New York: Columbia University Press.

Becker, G. S. 1962. Investment in human capital: A theoretical analysis. The journal of political economy, 70(5), 9-49.

Benos, N. and S. Karagiannis. 2016. "Do education quality and spillovers matter? Evidence on human capital and productivity in Greece." Economic Modelling, 54, 563-573. https://doi.org/10.1016/j.econmod.2016.01.015

Central Bank of Nigeria. 2018. Statistical bulletin and statements of account. Abuja: Central Bank of Nigeria.

Chang C., Wang P., \& Lui J. (2016). Knowledge spillovers, human capital and productivity. Journal of Macroeconomics, 47, 214-232. https://doi.org/10.1016/j.jmacro.2015.11.003

Dias, J., \& Tebaldi, E. (2012). Institutions, human capital, and growth: The institutional mechanism, Structural Change and Economic Dynamics, 23, 300-312. https://doi.org/10.1016/j.strueco.2012.04.003 
Dutta Nand Sobel, R.S. (2017). Entrepreneurship and human capital: The role of financial development. International Review of Economics and Finance, xxx, 1-14, https://doi.org/10.1016/j.iref.2018.01.020

Eigbiremolen, G.O., \& Anaduaka, U.S. (2014). Human capital development and economic growth: The Nigeria experience. International Journal of Academic Research in Business and Social Sciences, 4(4), 25 - 35.

Escosura, L.P., \& Roses, J.R. (2010). Human capital and economic growth in Spain, 18502000. Explorations in Economic History, 47, 520-532. doi:10.1016/j.eeh.2010.02.002

Fashina, O. A., Asaleye, A. J., Ogunjobi, J. O., \& Lawal, A. I. (2018). Foreign Aid, Human Capital and Economic Growth Nexus: Evidence from Nigeria. Journal of International Studies, 11(2), 104-117. https://doi.org/10.14254/20718330.2018/11-2/8

Glewwe, P., Maiga, E., \& Zheng, H. (2014). The contribution of education to economic growth: A review of the evidence, with special attention and an application to sub-Saharan Africa. World Development, 59(1), 379-393.

Gyimah-Brempong, K., Paddison, O., \& Mitiku, W. (2006). Higher Education and Economic Growth in Africa, Journal of Development Studies, 42 (3), 509 - 529.

Gyimah-Brempong, K. \& Wilson, M. (2004). Health Human Capital and Economic Growth in sub-Saharan African and OECD countries. The Quarterly Review of Economics and Finance, 44, 296 - 320.

IMF, (2018) World Economic Outlook.

Kim, D. \& Lee, C. (2007). On-the-job Human Capital Accumulation in a Real Business Cycle Model: Implications for Intertemporal Substitution Elasticity and Labour Hoarding

Lee Jand Lee, H. (2016). Human capital, in the long run. Journal of Development Economics, 122, 147-169. https://doi.org/10.1016/j.jdeveco.2016.05.006

Lerner, J. 2002. When Bureaucrats Meet Entrepreneurs: The Design of Effective'Public Venture Capital' Programmes. The Economic Journal, 112, F73-F84.

Li T. and Wang Y. (2016), Growth channels of human capital: A Chinese panel data study. China Economic Review, https://doi.org/10.1016/j.chieco.2016.11.002

Li, T., Lai, J., Wang, Y., \& Zhao, D. (2016). Long-run relationship between inequality and growth in post-reform China: New evidence from a dynamic panel model. International Review of Economics and Finance, 41, 238-252.

Lucas, R. E. (1988). On the mechanics of economic development. Journal of Monetary Economics, 22, 3-42.

Mankiw, N. G., Romer, D., \& Weil, D. (1992). A contribution to the empirics of economic growth. Quarterly Journal of Economics, 107, 407-437.

Masih A., \& Masih R. (1996). Energy consumption, real income and temporal causality: Result from a multi-country Study based on cointegration and Error Correction Modeling Techniques. Energy Economics 18, 165-183.

Mulligan, C., \& Sala-i-Martin, X. (1992). Transitional dynamics in two-sector models of endogenous growth. National Bureau of Economic Research working paper no.w3986.

Nelson, R., \& Phelps, E. (1966). Investment in humans, technological diffusion, and economic growth. American Economic Review, 61, 69-75.

Ogundari, K., \& Awokuse, T. (2018). Human capital contribution to economic growth in subSaharan Africa: Does health status matter more than education?. Economic Analysis and Policy, 58, 131-140. https://doi.org/10.1016/j.eap.2018.02.001

Ogunleye, O.O., Owolabi, O.A., Sanyaolu, O.A., \& Lawal, O.O. (2017). Human Capital Development and Economic Growth in Nigeria. Journal of Business Management, 3(8), $17-37$. 
Onkelinx, J., Manolova, T.S., \& Edelman, L.F. (2016). The human factor: Investments in employee human capital, productivity, and SME internationalization. Journal of International Management, 22, 351-364. https://doi.org/10.1016/j.intman.2016.05.002

Perli, R., \& Sakellaris, P. (1998). Human Capital Formation and Business Cycle Persistence. Journal of Monetary Economics, 42, 67 - 92.

Pesaran, M., \& Shin, Y. (1997). Cointegration and Speed of Convergence to Equilibrium, Journal of Econometrics, 71(1 - 2), 117 - 143.

Popoola, O., Asaleye, J., \& Eluyela, F. (2018). Domestic resource mobilization and agricultural productivity growth in Nigeria. Journal of advanced research in law and economics.

Romer, P. (1990). Human capital and growth: Theory and evidence. Carnegie Rochester Conference Series on Public Policy, 32. (pp. 251-286), 251-286.

Schultz, T. W. 1961. Investment in human capital. The American economic review, 1(2), 1-17.

Scott-Clayton, J. 2013. Information Constraints and Financial Aid Policy. In: Heller, D. \& Callender, C. (eds.) Student Financing of Higher Education: A Comparative Perspective, London: Routledge International Studies in Higher Education, 75-110.

Spence, M. (1973). Job Market Signalling. The Quarterly Journal of Economics, 87(3), 355374.

$\mathrm{Su}, \& \mathrm{Liu}, \mathrm{Z}$. (2016). The impact of foreign direct investment and human capital on economic growth: Evidence from Chinese cities. China Economic Review, 37, 97-109. https://doi.org/10.1016/j.chieco.2015.12.007

Teixeiraa, A.A.C., \& Queiros, A.S.S. (2016). Economic growth, human capital and structural change: A dynamic panel data analysis. Research Policy 45, 1636-1648. https://doi.org/10.1016/j.respol.2016.04.006

Tingting Li \& YongWang (2016). Growth channels of human capital: A Chinese panel data study. China Economic Review.

Trostel, P., Walker, I., \& Woolley, P., (2002). Estimates of the economic return to schooling for 28 Countries. Labour Economics, 9 (1).

Urgaia, W.R. (2018). The role of Human Capital Resources in East African Economies, GLO Discussion Paper, No 218, Global Labour Organization, Maastricht.

Vandenbussche, J., Aghion, P., \& Meghir, C. (2006). Growth, distance to frontier and composition of human capital. Journal of Economic Growth, 11(2), 97-127.

World Bank. (1995). Workers in an integrating world: World Bank Development Report $(W B D R)$. Washington D. C: Oxford University Press. 